\title{
A study of maternal serum calcium and serum magnesium levels in pre- eclamptic and normotensive pregnancies
}

\author{
Pranshi Gupta* \\ Department of Obstetrics and Gynecology, Tirath Ram Shah Charitable Hospital, New Delhi, India \\ Received: 28 May 2020 \\ Accepted: 06 July 2020 \\ *Correspondence: \\ Dr. Pranshi Gupta, \\ E-mail: pranshigupta16@gmail.com \\ Copyright: () the author(s), publisher and licensee Medip Academy. This is an open-access article distributed under \\ the terms of the Creative Commons Attribution Non-Commercial License, which permits unrestricted non-commercial \\ use, distribution, and reproduction in any medium, provided the original work is properly cited.
}

\begin{abstract}
Background: Hypertensive disorders are major factors responsible for morbidity and mortality in pregnancy and preeclampsia is the leading cause. The etiopathology of pre-eclampsia is not known even after significant research done on it. A strong strategy in its management is to try to reduce the incidence and severity by predicting its occurrence. In this study, the effect of serum calcium and serum magnesium levels is being investigated with occurrence preeclampsia.

Methods: Total 120 pregnant patients attending Tirath Ram Shah Hospital were included in the study. They were divided into two groups namely normotensive and hypertensive of 60 each. The serum calcium and serum magnesium levels were estimated and the correlation of these levels was studied with the pre-eclampsia related factors. The data was analysed by application of statistical test of significance.

Results: Mean serum calcium level in the normotensive group was $10.119 \pm 1.27 \mathrm{mg} / \mathrm{dl}$ while mean serum calcium level in the hypertensive group was $9.461 \pm 1.164$. Mean serum magnesium level in the normotensive women in the study was $1.979 \pm 0.405 \mathrm{mg} / \mathrm{dl}$. In the hypertensive women, mean serum magnesium level was $1.723 \pm 0.414 \mathrm{mg} / \mathrm{dl}$.

Conclusions: This study shows that low levels of calcium and magnesium are found in serum of pre-eclampsia patients as compared to normotensive cases of the study population. The severity of pre-eclampsia is inversely proportional to the levels of serum calcium and magnesium.
\end{abstract}

Keywords: Hypertensive disorder in pregnancy, Pre-eclampsia, Serum calcium, Serum magnesium

\section{INTRODUCTION}

Pregnancy is a normal physiological state. But pregnancy and its complications are the cause of about 600,000 women deaths every year in the world, and half of them are due to high risk pregnancies. ${ }^{1}$ Pre-eclampsia is one of the most common causes of maternal and fetal morbidity and mortality. It is a multi-systemic and multi-factorial pregnancy specific disorder that is very common, yet very less understood. Why the pregnancy incites or aggravates hypertensive vascular disease remains unsolved in spite of years of intensive research worldwide. The incidence of pre-eclampsia in developing nations is 4 to $18 \% .^{2} 16 \%$ of all maternal mortality in developed countries and $9 \%$ of maternal mortalities in
Asia and Africa are said to be due to hypertensive disorders in pregnancy. ${ }^{3}$ Hypertensive disorders rank third on the list of causes of maternal mortality, preceded by haemorrhage and infection. ${ }^{4} \mathrm{~A}$ worldwide perinatal and neonatal mortality rate of $10 \%$ is associated with preeclamptic disorders, with prematurity as the most common cause of neonatal death. ${ }^{5}$

The pathophysiology of pre-eclampsia involves maternalfetal physiological perturbations. Although the exact etiology is unknown, the pathophysiological mechanism is characterized by a failure of the trophoblastic invasion of the spiral arteries which may be associated with an increased vascular resistance of the uterine artery and a decreased perfusion of the placenta. Pre-eclampsia has 
been dubbed as the 'disease of theories' because of the multiple hypothesis that have been proposed to explain its occurrence.

The greatest impact of pre-eclampsia is in developing countries where it accounts for a striking increase in maternal mortality. Pregnant women in developing countries have been reported to consume diet with lesser amounts of essential minerals and vitamins. An inadequate intake might be harmful not only for the mother but also for the growing fetus. Hypertensive disorders account for 40,000 maternal deaths annually. ${ }^{6}$ Due to this, methods to reduce the risk of hypertensive disorders in pregnancy have received considerable attention. A varied number of dietary deficiencies or excesses have been blamed as the cause for preeclampsia.

Previous reports have considered an association between pre-eclampsia and serum calcium and serum magnesium levels. Physiologically, calcium plays an important role in muscle contraction and regulation of water balance in cells. Low serum calcium may cause high blood pressure by stimulating parathyroid hormone and renin release and also by inducing vasoconstriction by increasing its level in vascular smooth muscle. Calcium might also have an indirect effect on smooth muscle function by increasing magnesium levels. Magnesium is present in more than 300 enzymes. It plays a crucial role in ATP metabolism. It also acts as a calcium channel antagonist. It acts as a potent vasodilator. Its depletion increases vasoconstrictor effect of angiotensin-II and noradrenaline, leading to increase in blood pressure.

However, the role of calcium and magnesium in pregnant women is still being discussed. Reports from clinical studies are inconsistent on their role in pre-eclampsia development. Some studies have shown that decrease in serum calcium and/or magnesium may potentiate pathogenesis of pre-eclampsia. $^{7-9}$ Others have failed to show any association between the levels of serum calcium and magnesium and prevalence of preeclampsia. $^{10}$

\section{METHODS}

The study was conducted in the department of obstetrics and gynecology, Tirath Ram Shah Charitable Hospital, New Delhi. Study population comprised pregnant women attending routine antenatal clinic during July 2018 to May 2019. This study is a case control study. The study constituted 120 members, between 32 and 40 weeks of gestation. This included 60 normotensive women and 60 pre-eclamptic women.

The patients were included in the case group were singleton pregnancy and between age of 18 to 40 years. Pre-eclampsia was diagnosed based on standard criteria, where in blood pressure $\geq 140 / 90 \mathrm{mmHg}$ on 2 separate occasions 6 hours apart and proteinuria with or without end-organ involvement. Significant proteinuria is $\geq 1+$ dipstick in 2 midstream urine samples collected 4 hours apart, or more than $300 \mathrm{mg}$ in 24-hour urine, in more than 32 weeks of gestation. The control group included singleton pregnancy with more than 32 weeks gestational age between age 18 to 40 years. The patients with multiple pregnancy, chronic hypertension, gestational diabetes mellitus, renal or cardiovascular disease, thyroid disorder and anaemia were excluded in the study.

An approval of the study protocol was obtained from the ethical committee prior to the commencement of the study. Patients were selected for the study based on the inclusion criteria and by subjecting them to history taking, clinical examination (general physical examination, vitals, systemic examination, obstetric examination). Written informed consent was obtained from each woman before inclusion in the study. A standard interview-based questionnaire was used to obtain data on demography, clinical and family history. Gestational age was determined based on last menstrual period and confirmed by first trimester scan. If the difference between the 2 gestational ages calculated by last menstrual period and first trimester scan was more than 5 days, gestational age was confirmed by ultrasonography at 11-14 weeks (nuchal translucency, nasal bone scan). All the study population was followed up till delivery. Serum calcium levels were estimated by Roche kit by 5-nitro-5'-methyl BAPTA method. Serum magnesium was estimated by Roche kit by Xylidyl blue method.

Univariate and bivariate analysis were performed to assess the differences in demographic, anthropometric and biochemical parameters. Descriptive means, standard deviations and/or distributions were generated for all study variables. Pearson's correlation was used to study the correlation among the study parameters. Results were summarized in a comparison table of mean serum calcium and magnesium levels in women from the 2 groups using p-values and independent t-tests.

\section{Statistical analysis}

A p-value $<0.05$ was considered statistically significant. The data was analysed using SPSS statistical software (version 20.0).

\section{RESULTS}

A total 120 pregnant women of gestational age ranging from 32 to 40 weeks of gestation were recruited for the study. Out of them, 60 women were normotensive who comprised the control group. 60 women were preeclamptic, comprising the study group. Serum calcium and magnesium levels were analysed for all the women. All the women were followed up till delivery.

The mean age of control group was $24.6 \pm 4.28$ years whereas mean age of study group was $24.316 \pm 4.43$ years. 
p-value was 0.156 which is statistically insignificant. The majority of the pre-eclamptic women were primigravida $(75 \%)$. Out of the total 60 pre-eclamptic women, 44 (73.3\%) had mild pre-eclampsia while $16(26.7 \%)$ had severe pre-eclampsia. In the pre-eclamptic group, 20 (33.3\%) patients had no proteinuria, $23(38.33 \%)$ of preeclamptic women had urine albumin $+1,10(16.66 \%)$ had urine albumin +2 while $7(11.66 \%)$ had urine albumin $\geq+3$. Majority $(65 \%)$ of the patients developed pre- eclampsia at 32-34 weeks of gestation. 28 (46.7\%) of women who had pre-eclampsia required no treatment and were managed on close observation. 26 (43.3\%) were started on antihypertensive drugs to manage their condition. $6(10 \%)$ had to be given magnesium sulphate along with antihypertensive drugs, either for prophylactic or therapeutic purposes. Among the patients who had preeclampsia, $4(6.7 \%)$ developed placental abruption, while $1(1.7 \%)$ developed eclampsia.

Table 1: Comparison of serum magnesium levels between pre-eclamptic and normotensive women.

\begin{tabular}{|llllll|}
\hline & Group & N & Mean & STD. deviation & STD. error mean \\
\hline \multirow{2}{*}{$\begin{array}{l}\text { Serum } \\
\text { magnesium }\end{array}$} & Control & 60 & 1.9795 & 0.40559 & 0.05236 \\
\cline { 2 - 6 } & Study & 60 & 1.7238 & 0.41423 & 0.05348 \\
\hline
\end{tabular}

p-value is 0.001 .

Table 2: Relationship between serum magnesium level and degree of pre-eclampsia.

\begin{tabular}{|c|c|c|c|c|c|c|c|c|}
\hline \multirow{3}{*}{$\begin{array}{l}\text { Degree of pre- } \\
\text { eclampsia }\end{array}$} & \multicolumn{8}{|c|}{ Serum magnesium } \\
\hline & \multirow[b]{2}{*}{$\mathbf{N}$} & \multirow[b]{2}{*}{ Mean } & \multirow[b]{2}{*}{ Std. deviation } & \multirow[b]{2}{*}{ Std. error } & \multicolumn{2}{|c|}{$95 \%$ CI for mean } & \multirow[b]{2}{*}{ Maximum } & \multirow[b]{2}{*}{ Minimum } \\
\hline & & & & & $\begin{array}{l}\text { Lower } \\
\text { bound }\end{array}$ & $\begin{array}{l}\text { Upper } \\
\text { bound }\end{array}$ & & \\
\hline Normal & 60 & 1.9795 & 0.40559 & 0.05236 & 1.8747 & 2.0843 & 1.26 & 2.51 \\
\hline Mild & 44 & 1.7716 & 0.42166 & 0.06357 & 1.6434 & 1.8998 & 1.24 & 2.41 \\
\hline Severe & 16 & 1.5925 & 0.37432 & 0.09358 & 1.3930 & 1.7920 & 1.24 & 2.44 \\
\hline Total & 120 & 1.8517 & 0.42791 & 0.03906 & 1.7743 & 1.9290 & 1.24 & 2.51 \\
\hline
\end{tabular}

p-value is 0.001 .

Table 3: Comparison of serum calcium levels between pre-eclamptic and normotensive women.

\begin{tabular}{|llllll|}
\hline & Group & N & Mean & Std. deviation & Std. error mean \\
\hline \multirow{2}{*}{ Serum calcium } & Control & 60 & 10.1197 & 1.27066 & 0.16404 \\
\cline { 2 - 6 } & Study & 60 & 9.4617 & 1.16467 & 0.15036 \\
\hline
\end{tabular}

p-value is 0.004 .

Table 4: Relationship between serum calcium level and degree of pre-eclampsia.

\begin{tabular}{|c|c|c|c|c|c|c|c|c|}
\hline \multirow{3}{*}{$\begin{array}{l}\text { Degree of pre- } \\
\text { eclampsia }\end{array}$} & \multicolumn{8}{|c|}{ Serum calcium } \\
\hline & \multirow[b]{2}{*}{$\mathbf{N}$} & \multirow[b]{2}{*}{ Mean } & \multirow[b]{2}{*}{$\begin{array}{l}\text { Std. } \\
\text { deviation }\end{array}$} & \multirow{2}{*}{$\begin{array}{l}\text { Std. } \\
\text { error }\end{array}$} & \multicolumn{2}{|c|}{$95 \%$ CI for mean } & \multirow[b]{2}{*}{ Maximum } & \multirow[b]{2}{*}{ Minimum } \\
\hline & & & & & $\begin{array}{l}\text { Lower } \\
\text { bound }\end{array}$ & $\begin{array}{l}\text { Upper } \\
\text { bound }\end{array}$ & & \\
\hline Normal & 60 & 10.1197 & 1.27066 & 0.16404 & 9.7914 & 10.4479 & 7.73 & 12.10 \\
\hline Mild & 44 & 9.4991 & 1.14562 & 0.17271 & 9.1508 & 9.8474 & 7.86 & 11.70 \\
\hline Severe & 16 & 9.3588 & 1.24807 & 0.31202 & 8.6937 & 10.0238 & 7.94 & 11.54 \\
\hline Total & 120 & 9.7907 & 1.25785 & 0.11483 & 9.5633 & 10.0180 & 7.73 & 12.10 \\
\hline
\end{tabular}

p-value is 0.014 .

It can be very clearly seen that serum calcium and magnesium levels are significantly lower in pre-eclamptic women compared to normotensive women. The severity of pre-eclampsia is inversely proportional to the levels of serum calcium and magnesium.

The mean serum magnesium level in the control group in this study was $1.979 \pm 0.405 \mathrm{mg} / \mathrm{dl}$. In the study group, mean serum magnesium level was $1.723 \pm 0.414 \mathrm{mg} / \mathrm{dl}$. pvalue was 0.001 , which is statistically significant, indicating that serum magnesium levels are significantly lower in women who develop pre-eclampsia as compared to normotensive pregnant women. It is also observed that mean serum magnesium level in mild pre-eclampsia was $1.771 \pm 0.421 \mathrm{mg} / \mathrm{dl}$, while in severe pre-eclampsia was $1.592 \pm 0.374 \mathrm{mg} / \mathrm{dl}$, indicating that severe cases of pre- 
eclampsia had lower mean value of serum magnesium compared to mild cases ( $\mathrm{p}$-value $=0.001)$.

The mean serum calcium level in the control group was $10.119 \pm 1.27 \mathrm{mg} / \mathrm{dl}$ while mean serum calcium level in the study group was $9.461 \pm 1.164$, leading to the conclusion that serum calcium levels are significantly lower in pre-eclampsia patients compared to normotensive pregnant women ( $p$-value $=0.004$ ). The mean serum calcium level in mild pre-eclampsia was $9.499 \pm 1.145 \mathrm{mg} / \mathrm{dl}$, while in severe pre-eclampsia was $9.358 \pm 1.248 \mathrm{mg} / \mathrm{dl}$. p-value is 0.014 . Hence it can be concluded that there is a significant relationship between serum calcium level and degree of pre-eclampsia.

\section{DISCUSSION}

The mean serum magnesium level in the control group in the study was $1.979 \pm 0.405 \mathrm{mg} / \mathrm{dl}$. In the study group, mean serum magnesium level was $1.723 \pm 0.414 \mathrm{mg} / \mathrm{dl}$. pvalue was 0.001 , which is significant, indicating that serum magnesium levels are significantly lower in women who develop pre-eclampsia as compared to normotensive pregnant women. Ugwuja et al, conducted a study in Nigeria in 2016 which had the same result. ${ }^{11}$ They recruited 40 pre-eclamptic and 40 normotensive pregnant women in the study and measured their serum magnesium levels. They found that pre-eclamptic women had significantly $(\mathrm{p}<0.001)$ lower serum magnesium in comparison to their normotensive counterparts. So, they concluded that serum magnesium seems to play a crucial role in the pathophysiology of pre-eclampsia. Similar results were obtained by Bandebuche $S$ et al in a study where they concluded that serum magnesium levels are significantly decreased $(\mathrm{p}<0.001)$ in women of preeclampsia as compared to normal pregnant women. ${ }^{12}$ However, Darkwa et al, found no significant difference in the mean serum levels of magnesium between preeclamptic and normal pregnant women in a study conducted in 2017 in Ghana. ${ }^{13}$

Further, it was also seen in the study that mean serum magnesium level in mild pre-eclampsia was $1.771 \pm 0.421$ $\mathrm{mg} / \mathrm{dl}$, while in severe pre-eclampsia was $1.592 \pm 0.374$ $\mathrm{mg} / \mathrm{dl}$. p-value is 0.001 . So, there is a significant relationship between serum magnesium levels and degree of pre-eclampsia. Serum magnesium level is lower in severe pre-eclampsia than in mild pre-eclampsia. Similar findings were reported by Deshpande et al in a study conducted in D. Y. Patil Hospital in 2018. ${ }^{14}$ They reported that severe cases of pre-eclampsia had lower mean value of serum magnesium compared to mild cases. Moholkar et al came to a similar conclusion in a study conducted in Government Medical College, Miraj during 2008-2010. ${ }^{15}$ The study included 120 subjects who were divided into 3 groups: normotensive, mild pre-eclamptic and severe pre-eclamptic. They found the serum magnesium levels to be significantly decreased in severe pre-eclamptic group than that of mild pre-eclampsia.
In the present study, it is found that mean serum calcium level in the control group was $10.119 \pm 1.27 \mathrm{mg} / \mathrm{dl}$ while mean serum calcium level in the study group was $9.461 \pm 1.164$. p-value is 0.004 , which is statistically significant. So, it can be concluded from this study that serum calcium levels are significantly lower in preeclampsia patients compared to normotensive pregnant women. However, Roy HL et al in their study found that the mean serum calcium did not differ significantly between the subjects of pre-eclampsia and normal pregnant women $(\mathrm{p}=0.963) .{ }^{16}$ This was in contrast with several studies suggesting hypocalcaemic as a possible cause of pre-eclampsia. For example, Onyegbule OA et al conducted a study in 2014 in Nigeria and found that there is significant reduction in the level of serum calcium in pre-eclamptic women as compared to normotensive women $\quad(\mathrm{p}<0.001){ }^{8} \quad$ They suggested dietary supplementation or direct replacement therapy of calcium for women with pre-eclampsia. Another study by Pairu J et al compared serum calcium levels between 50 preeclamptic and 50 normal pregnant women. ${ }^{17}$ They found that serum calcium levels were significantly decreased in cases compared to controls $(\mathrm{p}<0.001)$. Their study supported the hypothesis that calcium deficiency might be one of the causes in the development of pre-eclampsia.

Further, it was seen that, mean serum calcium level in mild pre-eclampsia was $9.499 \pm 1.145 \mathrm{mg} / \mathrm{dl}$, while in severe pre-eclampsia was $9.358 \pm 1.248 \mathrm{mg} / \mathrm{dl}$. p-value is 0.014. So, it is seen that there is a significant relationship between serum calcium level and degree of preeclampsia. Hence it can be concluded that serum calcium level is lower in severe pre-eclampsia than in mild preeclampsia. Deshpande et al, also found similar results in their study done in $2018 .{ }^{14}$ They selected a total number of 256 cases in the third trimester of pregnancy and divided into study and control groups of 128 each. The 128 cases in the study group were further divided into 3 sub-groups- mild, moderate and severe based on their blood pressure readings. They found that though there was no specific decreasing trend observed with increase in the intensity of pre-eclampsia, the mean levels of serum calcium of all 3 sub-groups was towards the lower side, more so in the sub-group of severe cases. However, in a study conducted by Vafae et al, in Iran in 2014, it was found that the severity of pre-eclampsia was not influenced by the serum level of calcium. ${ }^{18}$

\section{CONCLUSION}

From the present study, though calcium and magnesium deficiencies cannot be pinpointed as the sole factors for the etiology of pre-eclampsia, it can be concluded that they have a definite role in the development of preeclampsia. Therefore, calcium and magnesium consumption should be encouraged during the second and third trimesters of pregnancy. The dietary supplements of calcium and magnesium in the form of milk, cheese, soya bean products, leafy vegetables etc during pregnancy could result in the reduction of incidence of pre- 
eclampsia. The direct supplementation therapy of these elements can be considered for women with preeclampsia to ensure less maternal and fetal complications.

Funding: No funding sources

Conflict of interest: None declared

Ethical approval: The study was approved by the Institutional Ethics Committee

\section{REFERENCES}

1. Bahadoran P, Zendehdel M, Movahedian A, Zahraee RH. The relationship between serum zinc level and preeclampsia. Iranian $\mathrm{J}$ Nurs Midwifery Res. 2010;15(3):120.

2. Villar J, Betran A, Gulmezoglu M. Epidemiological basis for the planning of maternal health services. WHO/RHR. 2001;111:298-302.

3. Khan KS, Wojdyla D, Say L, Gülmezoglu AM, V an Look PF. WHO analysis of causes of maternal death: a systematic review. Lancet. 2006;367(9516):106674.

4. Maternal Mortality, World Health Organisation fact sheet, November; 2016;3(4):89-93.

5. Maynard SE, Karumanchi SA. Angiogenic factors and preeclampsia. Paper presented at: Seminars in Nephrology. 2011;9:48-53.

6. Hofmeyr GJ, Duley L, Atallah A. Dietary calcium supplementation for prevention of pre-eclampsia and related problems: a systematic review and commentary. BJOG. 2007;114:933-43.

7. Chaurasia PP, Jadav PA, Jasani JH. Changes in serum calcium and serum magnesium level in preeclampsia vs normal pregnancy. Int $\mathbf{J}$ Biomed Adv Res. 2012;3:511-3.

8. Onyegbule OA, Meludu SC, Dioka CE, Udigwe GO, Udo JN, Ezidighoh AN, et al. Comparison of serum levels of calcium and magnesium among preeclamptics and normotensive pregnant women at Nnamdi Azikiwe University Teaching Hospital, Nnewi, Nigeria. Int J Res Med Sci. 2014;2:404-8.

9. Enaruna NO, Ande A, Okpere EE. Clinical significance of low serum magnesium in pregnant women attending the University of Benin Teaching Hospital. Niger J Clin Pract. 2013;16:448-53.

10. Cunningham FG. Hypertensive disorder in pregnancy. In: Cunningham FG, Leveno KJ, Bloom
SL, Hauth JC, Gilstre PL, W enstrom KD, editors. Textbook of Williams Obstetrics. 22nd ed. New York: McGraw-Hill; 2005:761-808.

11. Ugwuja EI, Famurewa AC, Ikaraoha CI. Comparison of serum calcium and magnesium between preeclamptic and normotensive pregnant Nigerian women in Abakaliki, Nigeria. Ann Med Health Sci Res. 2016;6(1):33-7.

12. Bandebuche S, Sagade B, Sontakke A. Serum magnesium in pregnancy induced hypertension. Int $\mathbf{J}$ Res Med Sci. 2013;1:413-6.

13. Darkwa EO, Antwi-Boasiako C, Djagbletey R, Owoo C, Obed S, Sottie D. Serum magnesium and calcium in preeclampsia: a comparative study at the Korle-Bu Teaching Hospital, Ghana. Integrated Blood Pressure Control. 2017;10:9.

14. Deshpande HG, Madkar CS, Bobe A, Nene V. Comparative study of serum calcium and serum magnesium levels in patients of preeclampsia and normotensive patients. Indian J Obstet Gynecol Res. 2018;5(4):465-70.

15. Moholkar AP, Bankar MP, Pujari KN, Jadkar SP. Serum calcium and magnesium levels in preeclampsia. IJPBS. 2014;4(3):42-5.

16. Roy HL, Nargis S, Rahman MM, Hossain MS, Amin MR, Majumder M, et al. Evaluation of Serum Calcium Levels in Pre-eclampsia. Medicine Today. 2018;30(2):57-60.

17. Pairu J, Triveni GS, Manohar A. The study of serum calcium and serum magnesium in pregnancy induced hypertension and normal pregnancy. Int $\mathbf{J}$ Reprod Contracept Obstet Gynecol. 2015;4(1):30-4.

18. Vafaei H, Dalili M, Hashemi SA. Serum concentration of calcium, magnesium and zinc in normotensive versus preeclampsia pregnant women: A descriptive study in women of Kerman province of Iran. Iranian J Reprod Med. 2015;13(1):23.

Cite this article as: Gupta P. A study of maternal serum calcium and serum magnesium levels in preeclamptic and normotensive pregnancies. Int $\mathbf{J}$

Reprod Contracept Obstet Gynecol 2020;9:3129-33. 